\title{
"I AM A FOOL": DR. HENRY CATTELL'S PRIVATE CONFESSION ABOUT WHAT HAPPENED TO WHITMAN'S BRAIN
}

\author{
Sheldon Lee Gosline
}

At his request, after death, his brain removed for science, phrenology, to study, and as the mortuary assistant carried it (I suppose in a jar but I hope cupped in his hands) across the lab's stone floor he dropped it.

-Thomas Lux, "Walt Whitman's Brain Dropped on Laboratory Floor"

THERE HAS BEEN much speculation about what really happened to Walt Whitman's brain. Ten years ago, Brian Burrell offered what up to now is the most extensive examination of the evidence. ${ }^{2}$ We know the brain was removed from Whitman's skull by Dr. Henry Ware Cattell, prosector of the American Anthropometric Society, during the March 27, 1892, autopsy of the poet. Cattell took it back to his lab to begin the process of preserving it. Fifteen years passed before another report on the condition of the poet's brain appeared: the then-renowned brain researcher Dr. Edward Anthony Spitzka announced in 1907 that "the brain of Walt Whitman, together with the jar in which it had been placed, was said to have been dropped upon the floor through carelessness in handling. Unfortunately, not even the pieces were saved" (quoted in Burrell 110). Over the years, the common narrative came to be that a clumsy laboratory assistant dropped the bottle containing Whitman's brain, after which it was discarded. This bumbling assistant even became a caricature, perhaps inspiring a vivid scene from the 1931 film Frankenstein, itself setting off the popular pseudo-science genre of the mad scientist. ${ }^{3}$ However, this was an historical fiction conceived to protect the reputation of the guilty party. As Burrell concludes, the brain "probably was dropped in the lab, as legend has it, perhaps by Cattell ... or during the risky process of making a cast of the hemispheres" (126). Burrell demonstrates that a number of other prominent brains in Cattell's care also had been ruined "through neglect" (127). So, "the evidence may implicate Cattell, but it does not rule out the possibility, however remote, that the brain will show up some day in a dusty attic or dank cellar vault" (129). According to Burrell, "the story may not 
have an ending" (130). A recent discovery, however, finally offers a definitive conclusion.

What really happened to Whitman's brain was a lifelong secret that followed Henry Ware Cattell (1862-1936) to the grave. ${ }^{4}$ Cattell was the head pathologist at the University of Pennsylvania's Wistar Institute and was perhaps best known for his 1903 Post-mortem Pathology. ${ }^{5}$ Whitman's brain was supposed to join those of other prominent Americans at the Wistar's collection of nineteenth-century elite brains donated in pre-mortem agreements by the members of the American Anthropometric Society, informally called the "Brain Club." This society was established in 1889, among a group of intellectuals fascinated by a growing appreciation of neurology. ${ }^{6}$ A believer in phrenology, Whitman made regular references to it in his writings, so it is no surprise that he was interested in having his brain studied after his death. ${ }^{7}$

I can now report that, in his private diary, Cattell confessed to accidentally destroying the poet's brain, and he agonized over the repercussions his blunder might have on his nascent career. ${ }^{8}$ Cattell's diary, covering parts of 1891-1893, sheds some light on what actually happened. This is an unpublished handwritten ledger with a cover page entitled "Diseases of Children." The bulk of the text consists of his diary for 1892, the fateful year when Whitman died and had an autopsy performed by Cattell, who removed his brain for scientific research. Cattell's ledger was sold on Ebay in December 2012, and I am grateful to Jason Cacioppo, its current owner, for sharing the unpublished data with me.

Unfortunately, Cattell's diary is silent about the Whitman autopsy, with no entry for the day in question, March 27, 1892. It is, however, revelatory concerning the destruction of the poet's brain. There are sporadic diary entries for 1891 (March 2 to September 14), then a gap during the time of the Whitman autopsy. Dated entries resume beginning May 23, 1892. At first optimistic, the diary entries are sporadic. Many day-pages have little or no data. Cattell had recently received the post of anatomical demonstrator for the University of Pennsylvania, so 1892 started out as a great year for him. He records that he attended his first professional baseball game on July 20, 1892, notes that he got new glasses (even recording his lens correction) on September 30, 1892, and records the passing of his thirtieth birthday on October 7.

But after October 14, 1892, the diary entries are increasingly dark and self-deprecating, expressing financial concerns, doubts, and even confessions of suicidal thoughts. The pivotal moment concerns an unexplained confession on October 14, 1892: "I am a fool." This begs the obvious question, why does Cattell call himself a fool? The prior day his notes include this reminder: "Prepare specimens for 
path. soc. [Pathological Society of Philadelphia]." Hypothetically, among those specimens was Whitman's brain, as yet undamaged. By itself, of course, "I am a fool" could relate to anything, and even if it had concerned Whitman's brain it does not by itself tell us why Cattell wrote it. Two days later, though, on Sunday, October 16, Cattell made a more specific confession: "I wish that I knew of the best way of keeping an account of my work. It often seems to me that I am so forgetful and yet I remember certain things which others might not be able to mind." Are the two confessions somehow related? Historical research is filled with such tantalizing back alleys and dead-ends, and at first this seems like another one. However foolish Cattell may have felt on October 14, by October 31 he was excited, noting "Pay day at the University [of Pennsylvania] to-morrow. I will get the largest sum which I have ever received at once clear viz. $\$ 1831 / 3$, the first annual check being the only one larger than this, but over $\$ 100$ having to be directly paid out for work done."

Cattell was sometimes more candid and reflective, although still cryptic. Skipping ahead to an entry on April 13, 1893, Cattell wrote, "I am a peculiar man in many ways. Why did I get rid of Edwards-in all probability because I was jealous of him." Edwards was apparently Cattell's assistant, perhaps the one Cattell managed to blame for the loss of Whitman's brain. But the biggest confession was yet to come.

In the privacy of his journal, about a month after his confession to being "a peculiar man," Cattell fully confessed to the Whitman brain disaster. In a candid moment of reflection he states plainly: "I am a fool, a damnable fool, with no conscious memory, or fitness for any learned position. I left Walt Whitman's brain spoil by not having the jar properly covered. Discovered it in the morning. This ruins me with the [American] Anthropometric Society, and [Harrison] Allen, perhaps with [William] Pepper [Jr], [Isaac Newton] Kerlin \&c. How I ever got in such financial straights [I] do [not] know. When I broke with Edwards I should have told him to go to thunder. Borrowed over $\$ 500$ more from $\mathrm{P} \& \mathrm{M}[\mathrm{Pa}$ and $\mathrm{Ma}$, i.e., his parents]. They are too good \& kind. I would have killed my self before this a dozen times over if it had not been for them" ( $p$ 179). ${ }^{9}$ This reflection, on Monday, May 15, 1893, clarifies the briefer confession of October 14, 1892, and links with the Edwards dismissal. Edwards appears to have taken the official blame until now.

Self-doubt continued to plague Cattell. On September 18, 1893, he wrote, "I should be happy and I suppose in my way I am. Except for my parents I could go to Africa or die and I w[ou]ld be in no way missed." On September 30, 1893, he wrote, "I look back on my confidence and self possession of last year as somehow wonderful. I now know that I do 
not know enough pathology for the position which I occupy." Financial woes continued to plague Cattell for some time, but his diary entries were not all doom and gloom. On October 17, 1893, he wrote: "My finances were never in so flourishing a condition and I felt like writing the other day that I was happier than I have ever been." The diary entries present overall evidence of wild mood swings, between deep suicidal depression and manic, grand visions of success.

So, there it is, as clear as can be. Sometimes the facts do finally emerge, but (as in this case) it would always be welcome to learn more details. Who threw away Whitman's brain? What exactly does it mean that it was spoiled by not having the jar properly covered? Was it knocked over by the cleaners? Did something strange get into the jar that contaminated it? Was Edwards at all involved or only a convenient scapegoat? Reading between the lines, Cattell appears to be the victim of extortion, perhaps by the disgraced assistant. Then, too, why put this incriminating evidence down on paper at all, risking public exposure? Clearly Cattell wanted to leave a confession that one day would become public - which now, 120 years later, has finally happened.

At the end of this ledger, there is a poem Cattell wrote on June 9, 1924. Perhaps it best summarizes how he viewed his life, disregarding his many honors as fraudulently gained. He not only had his university staff income, but also charged assistants to privately assist him, provided post-mortems and expert testimony for a fee, ran a medical journal for a profit, and was a successful and lauded author. All of this was possible because he had evaded disgrace from the Whitman incident. Still the guilt plagued him through his career:

Those many worldly things

Which lots of money brings

He had, too true, galore.

And honors many more

Than fall to better men

Were won with learned pen.

Now envy not his lot

For happy was he not

His sense of justice fair

Was found no longer there

A hell in every nook

For God he had forsook. (225)

Was it fair or ethical for a physician to hide such a major blunder? Should he have faced the consequences of his mistakes? Perhaps, toward the end, Cattell wanted to make a public confession, but enjoyed the fruits of his financial success too much to come clean. Clearly he could have 
destroyed these diary entries, but he chose instead to provide evidence to eventually set the record straight. Now that this hidden confession has finally been revealed, a long mystery is solved and perhaps the troubled spirits of both pathologist and poet can rest.

\section{University College London Centre for the History of Medicine}

\section{NOTES}

1 Thomas Lux, "Walt Whitman's Brain Dropped on Laboratory Floor," Massachusetts Review 33 (Spring 1992), 91.

2 Brian Burrell, “The Strange Fate of Whitman's Brain," Walt Whitman Quarterly Review 20 (Winter/Spring 2003), 107-133.

3 Cynthia Haven, "Frankenstein and Walt Whitman's brain: This is a grewsome story!" The Book Haven: Cynthia Haven's Blog for the Written Word (http://bookhaven. stanford.edu/2012/06/frankenstein-and-walt-whitmans-brain-this-is-a-grewsomestory/).

4 Sheldon Gosline, "I am a fool," The UCL Centre for the History of Medicine (Feb. 13, 2013). http://tinyurl.com/c5jrwn5. That blog entry is an earlier version of this essay.

5 Henry Ware Cattell, Post-mortem Pathology: A Practical Treatise for Students and Practitioners (Philadelphia: J.B. Lippincott, 1903).

6 Edward Anthony Spitzka, "A Study of the Brains of Six Eminent Scientists and Scholars Belonging to the American Anthropometric Society together with a Description of the Skull of Professor E. D. Cope," Transactions of the American Philosophical Society, New Series 21:4 (1907), 175-308.

7 See Arthur Wrobel, "Whitman and the Phrenologists: The Divine Body and the Sensuous Soul," PMLA 89:1 (January 1974), 17-23; and Nathaniel Mackey, "Phrenological Whitman," Conjunctions 29 (Fall 1997), 231-251.

8 Henry W. Cattell, Unpublished Diary of 1891-1893, 144,167,179; private collection of Jason Cacioppo. Since Henry Cattell had no children, the diary was presumably in the possession of descendents of Cattell's brother, James McKeen Cattell. The diary, along with Cattell's autopsy book, was sold on Ebay out of New Jersey in 2012. In the books were letters and personal stationery from Cattell's Philadelphia medical practice. Cattell lived in Browns Mill, New Jersey, at the time of his death. See obituaries of Cattell in the New York Post (March 9, 1936) and in Science 83 (March 13, 1936), 52.

9 Harrison Allen (1841-1897) was a Philadelphia physician and anatomist and chair of physiology at the University of Pennsylvania; William Pepper, Jr. (1843-1898) was a professor of medicine at the University of Pennsylvania and provost at the time of this entry; Isaac Newton Kerlin (1834-1893) was the superintendent of the Pennsylvania Institute for Feeble-Minded Children from 1863 to 1893 and a recognized expert on mental retardation. Cattell's parents were William Cassady Cattell (1827-1898), president of Lafayette College, and Elizabeth McKeen (1835-1917), who received a substantial inheritance from her father; William and Elizabeth often used their wealth and influence to help Henry and his brother, James McKeen Cattell (1860-1944), one of the pioneers of the field of psychology and a professor at the University of Pennsylvania and Columbia University. 